PAPER • OPEN ACCESS

\title{
Anodic Dissolution of Non-Ferrous Metals in a Glycerate-Alkali Electrolyte
}

To cite this article: V A Valnev et al 2020 IOP Conf. Ser.: Mater. Sci. Eng. 969012057

View the article online for updates and enhancements.

The Electrochemical Society

Advancing solid state \& electrochen science \& technolog 2021 Virtual Education

Fundamentals of Electrochemistry: Basic Theory and Kinetic Methods Instructed by: Dr. James Noël Sun, Sept 19 \& Mon, Sept 20 at 12h-15h ET

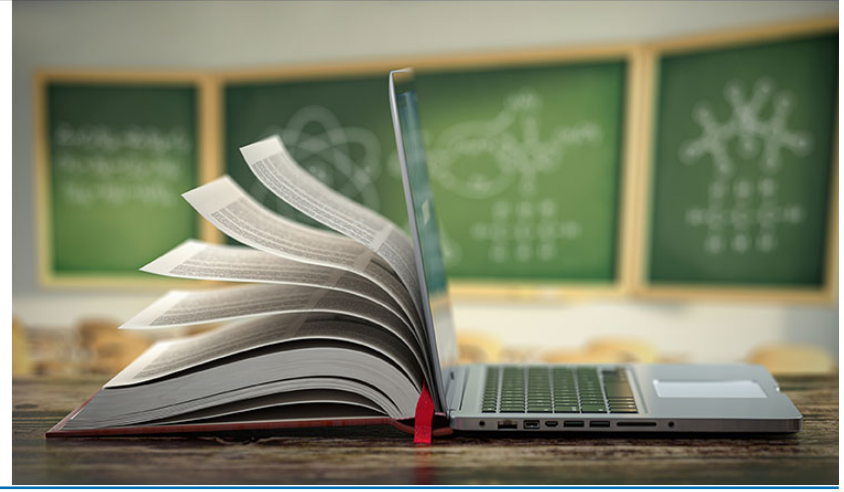




\title{
Anodic Dissolution of Non-Ferrous Metals in a Glycerate- Alkali Electrolyte
}

\author{
V A Valnev, V G Lobanov and D I Bludova \\ Department of Non-Ferrous Metallurgy, Ural Federal University, 17 Mira street, \\ Ekaterinburg city, 620002, Russia \\ E-mail: va.valnev@urfu.ru
}

\begin{abstract}
Studies have been conducted to assess the possibility of refining a lead collector containing precious metals, with the aim of obtaining lead using an economically viable and environmentally safe technology. A method of electrochemical selection in an alkaline glycerate electrolyte is proposed. The behavior of lead, silver and "silver crust" during anodic polarization in glycerate electrolyte was studied using the potentiodynamic method. "Silver crust" - type alloy of the following composition were used in this study, (wt.) \%: 77.9 Pb, 12.76 Zn, 3.53 Ag, $0.50 \mathrm{Cu}, \mathrm{Sb}$ 0.90. The studies were carried out using the method of a rotating disk. Studied the patterns of anodic oxidation of lead and impurities in alkaline-water-glycerate electrolytes, depending on the concentration of sodium hydroxide and glycerol in the electrolyte, the potential sweep rate.
\end{abstract}

\section{Introduction}

Anodic dissolution of non-ferrous metals and alloys is accompanied by the formation of a film of poorly soluble products on the surface of the anodes. The result of this process is the passivation of the anode, further dissolution slows down or stops completely. Metals such as lead, antimony, tin show a greater tendency to passivation. For this reason, electrochemical refining of alloys containing these metals in appreciable amounts is almost impossible.

The refinement of argentiferous lead by the pyrometallurgical method is accompanied by the production of silver crust, where precious metals are concentrated. Silver crust mostly contains lead, zinc, copper, bismuth, iron, tellurium and some other metals [1-4]. Improving the technology of complex processing of this multicomponent ingoing material is relevant.

\section{Current technologies}

The main purpose in the processing of silver crust is the selection of the extraction of precious metals. Traditional technologies are based on the distillation of crust in electrode furnaces with the aim of rundown to $90 \%$ zinc. The resulting residue is additionally cupelled, gold and silver remain in the bath of the furnace. The resulting alloy is poured into molds and sent for refining [5-8].

An alternative method was engineered in 1956 [3]. In an electrolyte containing $80 \mathrm{~g} / \mathrm{lof} \mathrm{Pb}$ and $100 \mathrm{~g} / 1$ of sulfamic acid, $95 \%$ of $\mathrm{Pb}$ is recovered into the cathode sediment and $100 \%$ of all precious metals are extracted into the slime. Energy consumption was $150 \mathrm{kWh}$ on ton of lead. The slime yield was approximately $17 \%$ by weight of the dissolved part of the anode, the sludge contained $82 \% \mathrm{Ag} ; 0.1$ 
$\mathrm{Au} ; 3.5 \% \mathrm{~Pb} ; 6.5 \% \mathrm{Cu} ; 3.5 \% \mathrm{Zn} ; 0.6 \% \mathrm{Bi}$ and $11.3 \% \mathrm{Sb}$. Metals are more electropositive than lead, (almost all impurities), remain in the anode slime, only tin is deposited with lead.

The electrolyte based on fluorosilicic acid and silicofluoride lead has become widespread in the electrorefining of raw lead. The lead to be refined, after debondering, was cast into anodes in the form of plates. The resulting sludge contained, \%: 12-20 Pb; 4-5 Ag; 6-15 Cu; 25-30 Sb; 9-15 As [3].

Known electroextraction of lead from nitric-acid solutions with obtaining cathodic sediment metallic lead and anodic - lead dioxide. The anode is titanium, the cathode is lead. When the concentration in the electrolyte, mol/l: $\mathrm{Pb} 0.5$ and $\mathrm{HNO}_{3} 0.5$ reached a current output of $94 \%$ without releasing nitrous gases. To reduce dendritic formation at the cathode, formic acid was added to the electrolyte in the amount of $\sim 440 \mathrm{~g}$ on 1 ton of cathode lead $[9,20]$.

Anodic dissolution of alloys containing in addition to lead, antimony and stannic in significant quantities - more than $10 \%$. Using these electrolytes is not possible, since stannic, even at roam temperature, forms an oxide film on the alloy surface, which causes irreversible passivation, reduces the rate of anodic dissolution.

With the joint processing of some lead-containing products at JSC "Uralelektromed", when refining lead, silver crust of the following composition is obtained, in mass $\%: 78.58 \mathrm{~Pb}, 15.95 \mathrm{Zn}, 0.47 \mathrm{Bi}, 0.22$ $\mathrm{Cu}, 0.36 \mathrm{Fe}, 0.63 \mathrm{Te}, 0.005 \mathrm{As}, 0.008 \mathrm{Sb}, 0.003 \mathrm{Sn}, 0.006 \mathrm{Ni}, 0.002 \mathrm{Al}, 0.02 \mathrm{Ca}, 0.01 \mathrm{Mg}, 4.31 \mathrm{Ag}$ [2]. Currently, measures are being taken to select a rational technology for the complex processing of such raw materials.

The purpose of this work is to create a cost-effective and environmentally friendly technology for the integrated extraction of valuable components from polymetallic alloys of reduced composition. Certain prospects in solving this problem have electrochemical selection in alkali-glycerate electrolyte [10-12]. According to [13], when using anodes made of an alloy of lead and antimony, anodic dissolution of both metals occurs under optimal conditions [14-15], but in some cases the surface of the anode is oxidized to lead dioxide, on which the reaction actually takes place.

\section{Research methods}

The specific task of the experiments was to study the laws of anodic polarization of the alloy and individual components in the electrolyte using the potentiodynamic method and the installation of a rotating disk electrode. This method was used to research specific action of polymetallic alloy and separate components in conditions of anodian polarization.

Electrodes from following metals were used in research: crust alloy, lead, antimony, tin, silver, copper and zinc. Chemical pure reagents were melted in an induction furnace and poured into graphite molds. The obtained cylindrical samples were processed to a diameter of $7 \mathrm{~mm}$ and pressed into fluoroplastic forms. The measurements were carried out by the method of a rotating disk using the Volta "EM-04" attachment, the rotation speed of $800 \mathrm{rpm}$ at room temperature is $25^{\circ} \mathrm{C}$.

Anodic dissolution of metals was studied using an IPC-Pro galvanostat-potentiostat, setting the potential change interval from -0.2 to 2 Volts with a sweep rate $100 \mathrm{mV} / \mathrm{s}$, since a dense passivation layer is formed at low speeds. Concentrations of alkali and glycerol in equal proportions were used: 25 , $50,100,150 \mathrm{~g} / \mathrm{l}$. Silver chloride reference electrode was used. The measurements were carried out in an open cell without separation of the auxiliary (platinum) electrode and the reference half-cell of porous glass or membrane partitions [16-19].

\section{Discussion of results}

The working surfaces of the disk electrodes were carefully processed before the experiment. Figures 14 show the potentiodynamic curves of the alloy, lead and silver, obtained under these conditions.

It is most likely that for electrodes made of lead and an alloy based on it, a significant anodic current near the potential of $0 \mathrm{mV}$ during polarization is associated with the formation of lead oxide, which begins in the cathode potential region $(-800 \mathrm{mV})$. Oxygen evolution becomes visually noticeable from 900-1200 mV. With increasing alkali concentration, the potential of this reaction shifts to the negative region. In the potential range of $600-800 \mathrm{mV}$, a peak is observed which is characteristic of a deeper 
oxidation of lead to dioxide. Under dynamic conditions of potential sweep, lead oxidation occurs at a satisfactory rate in the range of $200-800 \mathrm{mV}$ at a speed of $100-200 \mathrm{~mA} / \mathrm{cm}^{2}$.

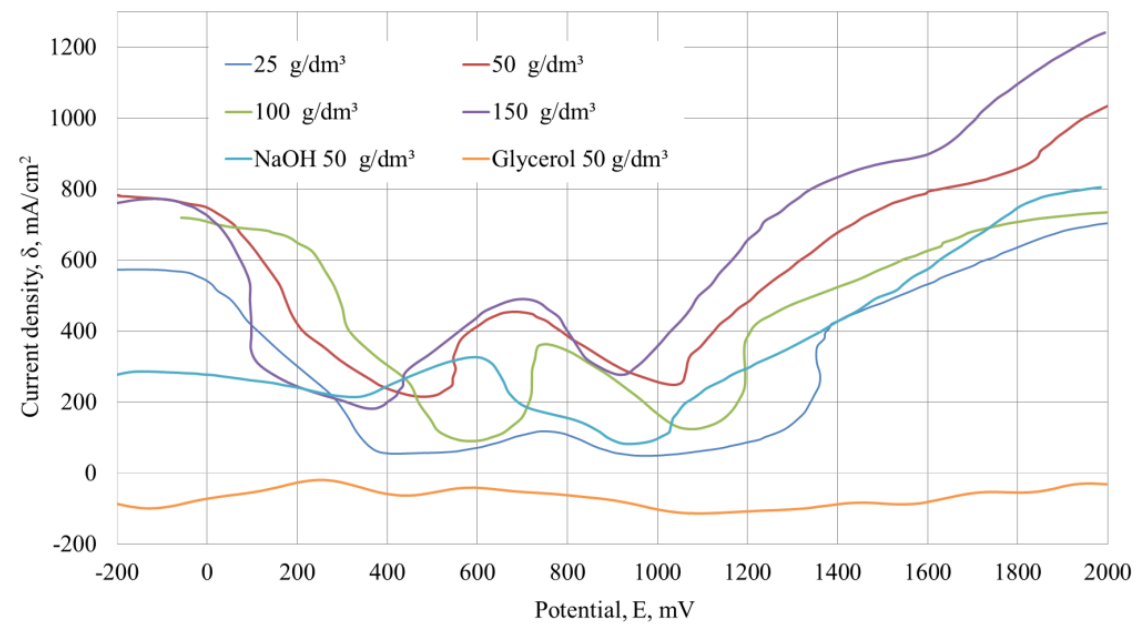

Figure 1. Polarization graphs of foam alloy.

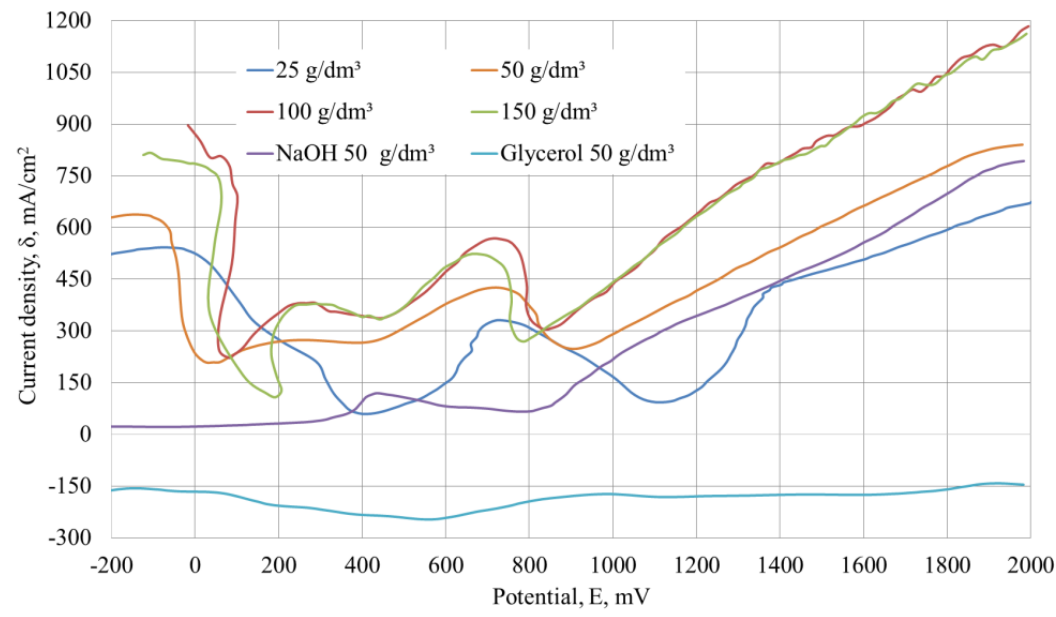

Figure 2. Polarization graphs of lead.

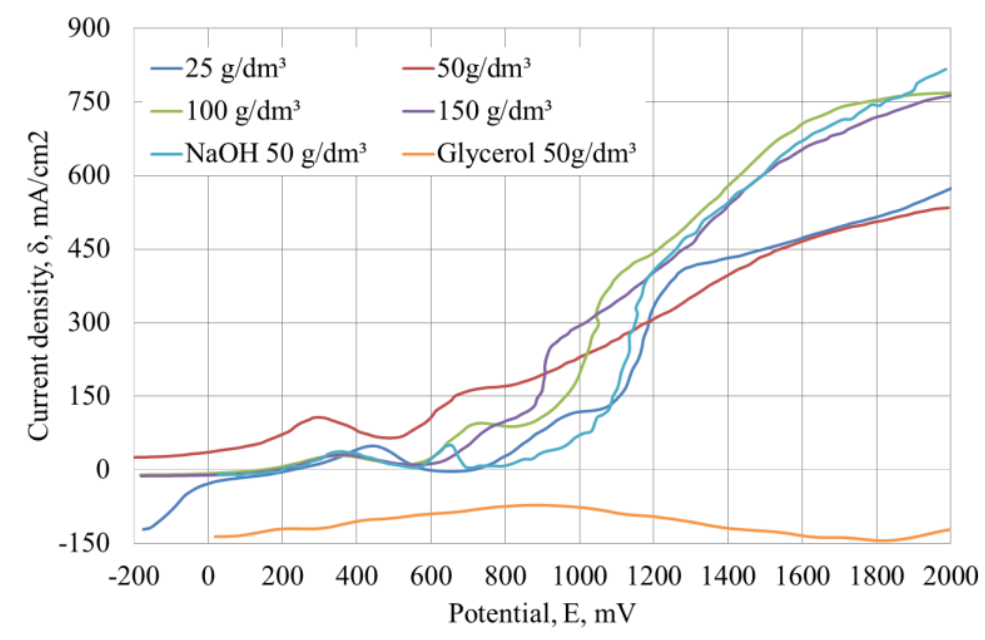

Figure 3. Polarization graphs of silver. 
Silver in electrolytes alkali-glycerin is passivated, when measuring the disk was covered with loose black sediment, at the potentials of 700-900 mV, the beginning of oxygen evolution was observed. The current density of anodic oxidation of silver does not exceed $10-20 \mathrm{~mA} / \mathrm{cm}^{2}$. According to the XRD, the precipitate is represented by silver oxide.

With an increase in the velocity of the potential sweep, the beginning of the noted processes shifts to the region of more negative potentials. The optimum scanning speed, allowing to identify confidently differences in the behavior of the alloy components lies in the range from $50 \mathrm{mV} / \mathrm{s}$ to $150 \mathrm{mV} / \mathrm{s}$.

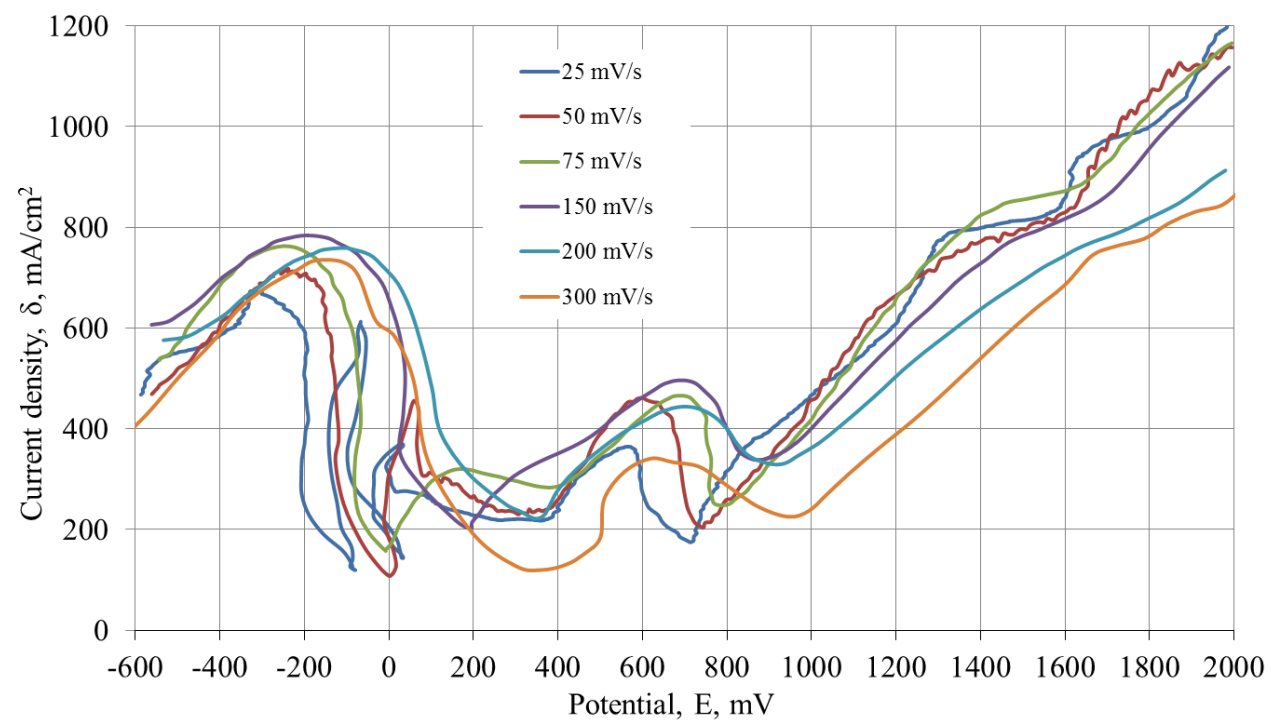

Figure 4. Polarization graphs of lead with different speed sweep at concentration $150 \mathrm{~g} / \mathrm{l} \mathrm{alkali/glycerol.}$

The graph shows that increasing the sweep rate leads the current density to lower range. However, too low scanning speeds result in significant increase of experiment time and distortion of the curves. According to the graphic optimal scanning speed is situated between $75 \mathrm{mV} / \mathrm{s}$ and $200 \mathrm{mV} / \mathrm{s}$, cause a scanning speed of experiments was $100 \mathrm{mV} / \mathrm{s}$.

\section{Conclusion}

The area of confident oxidation of lead in the alkaline-glycerate electrolyte corresponds to the potentials of $300-800 \mathrm{mV}$.

For the lead-based polymetallic alloy (silver crust) area of anodic oxidation corresponds to the potentials of 700-800 $\mathrm{mV}$.

The totality of the revealed regularities of the anodic polarization of polymetallic alloys gives reason to assume a confident transition to a solution of lead, antimony and tin, while silver, gold, tellurium are concentrated in the anode sludge.

Silver is oxidized to form an insoluble oxide, which forms the anode sludge. The issue of further research is determination of passivation process, influence on glycerol, electrolyte components, temperature, potential sweep and rotational disc speed.

\section{Reference}

[1] Ekilik V V 2004 Theory of corrosion and protection of metals (Rostov-on-the-Don) p 67

[2] Korolev A A, Krayukhin S A, Maltsev G I and Filatov E S 2004 Treatment of silver foam by vacuum distillation, J. Universities' Proceedings Non-Ferrous Metallurgy 4 21-29

[3] Baimakov Yu V and Zhurin V I 1963 Electrolysis in hydrometallurgy (Moscow: Metallurgizdat)

[4] Lebedev V A 1991 Theory of electrometallurgy of non-ferrous metals (Yekaterinburg: Ural Polytechnic Institute) 
[5] Loskutov F M 1965 Metallurgy of lead (Moscow: Metallurgy)

[6] Zaitsev V Ya and Margulis E V 1985 Lead and zinc metallurgy (Moscow: Metallurgy)

[7] Smirnov N P 1977 Lead refining and processing of industrial products (Moscow: Metallurgy)

[8] Abdeev M A, Getskin L S and Zaplavniy A Ya 1964 Modern methods of processing of lead-zinc ores and concentrates (Moscow: Metallurgy)

[9] Ostanova S V, Pashkov G L, Drozdov S V and Chubarov A V 2002 Study of the process of electroextraction of lead from nitric acid milieu Intellect-2002 327-328

[10] Bugenov E S, Nurlybaev R E, Shaidarbekova J K and Murzagulova A A 2013 Electrolysis of antimony from alkaline glycerate solutions $J$. Vestnik KazNTU 1 112-114

[11] Baiborodov P P and Ezhkov A B 1967 Glycerate method of lead raw material processing RU Author's Certificate $\mathbf{1 9 5 1 0 5}$

[12] Ishankhodzhaev S 1997 Chemistry and technology of production of antimony, lead and their compounds in the presence of polyatomic alcohols (Tashkent)

[13] Baizer M M and Lund H 1983 Organic electrochemistry (New York) p 285.

[14] Abdurakhmonov S 1997 The development and improvement of technology of extraction of gold and antimony from a refractory ores (Navoii)

[15] Kurkchi E U, Fedorenko A M and Kurkchi U M 2000 Solubility of antimony (III) oxides in aqueous solutions of polyatomic alcohols and calcium hydroxides, barium Scientific notes of Taurida state University 213 185-188

[16] Kogan M S 1994 Processing of sulphate-oxide fraction of lead accumulator scrap in conditions of small-scale production (St. Petersburg)

[17] Ostanina T N 2013 Theoretical electrochemistry: a laboratory course (Yekaterinburg: Ural Federal University)

[18] Kiselev M G, Mrochek J A and Drozdov A V 2014 Electrophysical and electrochemical methods of materials processing (Moscow: INFRA-M).

[19] Kholkina A S 2018 Electrochemical separation of Pb-Sb-Bi alloys in a mixture of potassium and lead chlorides (Yekaterinburg: Ural Federal University)

[20] Astapchik S V 2007 Electroextraction of lead from nitric acid electrolytes (Krasnoyarsk) 